\title{
Purification and characterization of pyruvate decarboxylase from Sarcina ventriculi
}

\author{
Susan E. LowE ${ }^{1 *} \dagger$ and J. Gregory Zeikus ${ }^{1,2,3} \dagger$ \\ ${ }^{1,2}$ Department of Biochemistry ${ }^{1}$ and Department of Microbiology and Public Health, ${ }^{2}$ Michigan State University, \\ East Lansing, Michigan 48824, USA \\ ${ }^{3}$ Michigan Biotechnology Institute, Lansing, Michigan 48909, USA
}

(Received 2 September 1991; revised 26 November 1991; accepted 19 December 1991)

\begin{abstract}
Pyruvate decarboxylase from the obligate anaerobe Sarcina ventriculi was purified eightfold. The subunit $M_{\mathrm{r}}$ was $57000 \pm 3000$ as estimated from SDS-PAGE, and the native $M_{\mathrm{r}}$ estimated by gel filtration on a Superose 6 column

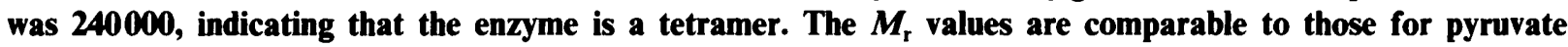
decarboxylase from Zymomonas mobilis and Saccharomyces cerevisiae, which are also tetrameric enzymes. The enzyme was oxygen stable, and had a $\mathrm{pH}$ optimum within the range 6.3-6.7. It displayed sigmoidal kinetics for pyruvate, with a $S_{0.5}$ of $13 \mathrm{mM}$, kinetic properties also found for pyruvate decarboxylase from yeast and differing from the Michaelis-Menten kinetics of the enzyme from $Z$. mobilis. No activators were found. $p$-Chloromercuribenzoate inhibited activity and the inhibition was reversed by the addition of dithiothreitol, indicating that cysteine is important in the active site. The $\mathbf{N}$-terminal amino acid sequence of pyruvate decarboxylase was more similar to the sequence of $S$. cerevisiae than $Z$. mobilis pyruvate decarboxylase.
\end{abstract}

\section{Introduction}

Pyruvate decarboxylase (EC 4.1.1.1) is a glycolytic enzyme catalysing the non-oxidative decarboxylation of pyruvate with the formation of acetaldehyde and carbon dioxide. Pyruvate decarboxylase is widespread in eukaryotes, including plants and yeast, but is relatively rare in prokaryotes, having been found only in Sarcina ventriculi (Stephenson \& Dawes, 1971), Zymomonas mobilis (Hoppner \& Doelle, 1983), Acetobacter peroxydans (De Ley \& Schell, 1959), Acetobacter suboxydans (King \& Cheldelin, 1954) and Erwinia amylovora (Haq \& Dawes, 1971). Purification of pyruvate decarboxylase has been achieved from two micro-organisms, Saccharomyces cerevisiae (Ullrich et al., 1966) and Z. mobilis (Hoppner \& Doelle, 1983; Neale et al., 1987a).

\footnotetext{
- Author for correspondence.

† The authors are also members of the Michigan State University Center for Microbiology Ecology, an NSF Science and Technology Center.
}

Abbreviation: TPP, thiamin pyrophosphate.

The amino acid sequence data reported in this paper have been submitted to PIR and have been assigned the accession number A38729.
In Sarcina ventriculi a branch point for glucose fermentation occurs at pyruvate, where oxidative decarboxylation of pyruvate by pyruvate dehydrogenase takes place, leading to the formation of acetate, and nonoxidative decarboxylation by pyruvate decarboxylase results in ethanol production (Stephenson \& Dawes, 1971). When grown at neutral $\mathrm{pH}, S$. ventriculi forms equal levels of acetate and ethanol and lower levels of formate, whereas growth at $\mathrm{pH} 3.0$ increases ethanol production (Lowe \& Zeikus, 1991). Regulation of carbon and electron flow in $S$. ventriculi is achieved at the branch point for pyruvate, with increased levels of pyruvate decarboxylase relative to pyruvate dehydrogenase at low pH (Lowe \& Zeikus, 1991).

Pyruvate decarboxylase from $S$. ventriculi was purified and characterized in order to compare its physical and chemical properties with the enzyme from Sacch. cerevisiae and $Z$. mobilis, and to provide information on the function of this enzyme in $S$. ventriculi.

\section{Methods}

\footnotetext{
Organism and culture conditions. Sarcina ventriculi strain JK was cultivated as described previously (Goodwin \& Zeikus, 1987). For large-scale fermentation, 16-litre glass carboys were used with 12 litres of medium, and the culture was stirred by placing the vessel on a
} 
magnetic stirrer. The $\mathrm{pH}$ of the medium was adjusted to $\mathrm{pH} 3.0$ with $6.5 \mathrm{M}-\mathrm{HCl}$ prior to inoculation and the medium was reduced by the addition of $25 \mathrm{ml}$ titanium/nitrilotriacetic acid solution (Moench \& Zeikus, 1983). The cells were harvested during mid-exponential phase by centrifugation using a Sharples centrifuge (Pennsalt Chemicals Corporation, Philadelphia, PA, USA), and washed with distilled water, before being stored at $-70^{\circ} \mathrm{C}$.

Enzyme assay. Pyruvate decarboxylase activity was determined aerobically at $37^{\circ} \mathrm{C}$ in a $1 \mathrm{ml}$ reaction mixture containing $0.1 \mathrm{M}$-sodium hydrogen maleate buffer (pH 6.5), $30 \mathrm{~mm}$-pyruvate, $0.1 \mathrm{~mm}$-thiamin pyrophosphate (TPP), $0.1 \mathrm{mM}-\mathrm{MgSO}_{4}, 0.3 \mathrm{~mm}-\mathrm{NADH}$ and 15 units alcohol dehydrogenase. The wavelength and absorption coefficient for NADH were $340 \mathrm{~nm}$ and $6220 \mathrm{~m}^{-1} \mathrm{~cm}^{-1}$, respectively.

Protein determination. Protein was determined by the method of Bradford (1976), with bovine serum albumin as the standard.

Purification of pyruvate decarboxylase. All steps were carried out under aerobic conditions at $4{ }^{\circ} \mathrm{C}$.

Step 1: Extraction and centrifugation. Cells of $S$. ventriculi $(30 \mathrm{~g})$ were suspended in $60 \mathrm{ml}$ distilled water, and disrupted by one passage through a French pressure cell (American Instrument Co.) at $124 \mathrm{MPa}$. The cell debris was removed by centrifugation at $12000 \mathrm{~g}$ for $15 \mathrm{~min}$, and the supernatant was used as the crude enzyme preparation.

Step 2: Ammonium sulphate fractionation. Solid $\left(\mathrm{NH}_{4}\right)_{2} \mathrm{SO}_{4}$ was added to the crude enzyme preparation initially at $30 \%$ saturation, with increases of $5 \%$ saturation until pyruvate decarboxylase was precipitated at $50 \%$ saturation. The precipitated material was resuspended in $0.1 \mathrm{M}$-piperazine/ $\mathrm{HCl}$ buffer (pH 6.5) containing $1 \mathrm{mM}-\mathrm{TPP}$ and $1 \mathrm{mM}$ $\mathrm{MgSO}_{4}$, and was washed and concentrated by ultrafiltration (YM 30 membrane; Amicon).

Step 3: Column chromatography. The above enzyme preparation was applied to a Q-Sepharose column $(3.0 \mathrm{~cm} \times 50 \mathrm{~cm})$, previously equilibrated with $0.1 \mathrm{M}$-piperazine $/ \mathrm{HCl}$ buffer $(\mathrm{pH} \mathrm{6.5)}$ containing $1 \mathrm{mM}-\mathrm{TPP}$ and $1 \mathrm{mM}-\mathrm{MgSO}_{4}$. The column was washed with the same buffer and the enzyme eluted with a 0 to $1.0 \mathrm{M}$ linear gradient of $\mathrm{NaCl}$ in the same buffer. Fractions containing pyruvate decarboxylase activity were pooled and concentrated by ultrafiltration. The sample was applied to a Sephacryl S-200 gel filtration column $(3.0 \mathrm{~cm} \times 50 \mathrm{~cm})$ equilibrated with $0.1 \mathrm{M}$-piperazine $/ \mathrm{HCl}$ buffer $(\mathrm{pH} \mathrm{6.5)}$ containing $1 \mathrm{mM}-\mathrm{TPP}, 1 \mathrm{~mm}-\mathrm{MgSO}_{4}$ and $0 \cdot 1 \mathrm{M}-\mathrm{NaCl}$. The fractions containing pyruvate decarboxylase were pooled and concentrated by ultrafiltration.

Electrophoresis and $M_{r}$ determination. SDS-PAGE was performed as described by Laemmli (1970), with $12 \%$ (w/v) acrylamide. Protein bands were visualized by Coomassie brilliant blue G-250 staining.

$M_{\mathrm{r}}$ values of purified pyruvate decarboxylase were determined by gel filtration on a Superose $6 \mathrm{HR}$ column (Pharmacia LKB Biotechnology) using a Waters FPLC system. The $\boldsymbol{M}_{\mathrm{r}}$ markers used (Sigma) were Blue Dextran $\left(M_{\mathrm{r}} 2000000\right)$, as an estimate of the void volume of the column, thyroglobulin (669000), apoferritin (443000), $\beta$-amylase (200000), alcohol dehydrogenase (150000) and BSA (66000). The $M_{\mathrm{r}}$ of the denatured protein was estimated by SDS-PAGE with low-range $M_{\mathrm{r}}$ standards (Bio-Rad): phosphorylase $b(97000)$, BSA $(66000)$, ovalbumin (43000), carbonic anhydrase (31000), soybean trypsin inhibitor (22000), and lysozyme (14000).

Amino acid sequence determination. The purified pyruvate decarboxylase was washed five times with double-distilled water using a Centricon-30 (Amicon) filtration device to remove contaminating salts and buffer from the solution. The $\mathrm{N}$-terminal amino acid sequence was determined by a protein sequencer model 477A (Applied Biosystems) with an on-line phenylthiohydantoin analyser (Applied Biosystems) in the Macromolecular Structure Facility, Department of Biochemistry, Michigan State University.

\section{Results and Discussion}

\section{Purification of pyruvate decarboxylase}

Pyruvate decarboxylase was purified from $S$. ventriculi as outlined in Table 1. Column chromatography was carried out at $\mathrm{pH} 6.5$, as lower $\mathrm{pH}$ values resulted in less enzyme adsorption and recovery from the column, and cation exchange was unsuccessful. The presence of the cofactors TPP and $\mathrm{MgSO}_{4}$ was essential for enzyme stability. The enzyme was unstable at $\mathrm{pH}$ values above 7.5 ; instability of pyruvate decarboxylase at alkaline $\mathrm{pH}$ has also been reported for the enzyme from yeast (Gounaris et al., 1971) and Z. mobilis (Neale et al., $1987 a$ ), with the tetrameric form denaturing to monomers. It appears as a significant enzyme in cells of $S$. ventriculi grown at $\mathrm{pH} 3$ (Fig. 1). The properties of pyruvate decarboxylase from $S$. ventriculi are shown in Table 2 and compared with properties of the same enzyme from $Z$. mobilis and Sacch. cerevisiae.

Pyruvate decarboxylase from $S$. ventriculi exhibits cooperative binding (Fig. 2), which has also been reported for the enzyme from Sacch. cerevisiae (Boiteux \& Hess, 1970; Ullrich \& Donner, 1970), and differs from the Michaelis-Menten kinetics found with pyruvate decarboxylase from Z. mobilis (Hoppner \& Doelle, 1983; Neale et al., 1987a).

Table 1. Purification of pyruvate decarboxylase from S. ventriculi

The data shown here are the mean results of three purifications.

\begin{tabular}{lccccc}
\hline \hline & $\begin{array}{c}\text { Total } \\
\text { protein } \\
\text { Step }\end{array}$ & $\begin{array}{c}\text { Total } \\
\text { activity } \\
\text { (units) }\end{array}$ & $\begin{array}{c}\text { Specific } \\
\text { activity } \\
\text { [units (mg } \\
\text { protein) }\end{array}$ & $\begin{array}{c}\text { Recovery } \\
(\%)\end{array}$ & $\begin{array}{c}\text { Purification } \\
\text { (-fold) }\end{array}$ \\
\hline Crude enzyme extract & 159 & 12800 & 12.9 & 100 & 1.0 \\
$\left(\mathrm{NH}_{4}\right)_{2} \mathrm{SO}_{4}$ precipitation & 54 & 9050 & 26.4 & 71 & 2.0 \\
Q-Sepharose & 5.6 & 1810 & 85 & 14 & 6.6 \\
Gel filtration & 2.7 & 724 & 103 & 6 & 8.0 \\
\hline \hline
\end{tabular}




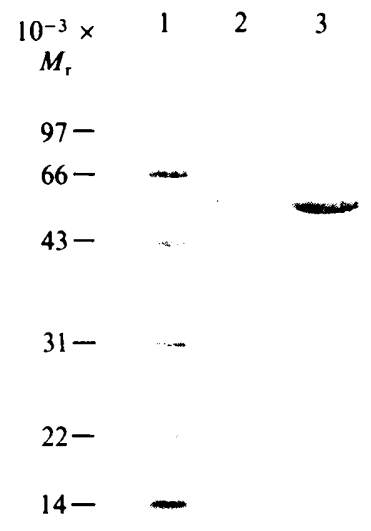

Fig. 1. SDS-PAGE of $M_{\mathrm{r}}$ markers (lane 1), cell extract of $S$. ventriculi, $10 \mu \mathrm{g}$ (lane 2), and purified pyruvate decarboxylase, $4 \mu \mathrm{g}$ (lane 3).

Table 2. Comparison of pyruvate decarboxylase from $S$. ventriculi, Z. mobilis and Sacch. cerevisiae

\begin{tabular}{|c|c|c|c|}
\hline Characteristic & S. ventriculi & Z. mobilis & Sacch. cerevisiae \\
\hline$M_{\mathrm{r}}(\mathrm{SDS})$ & $57000 \pm 3000$ & $59000 \pm 1000^{a, b}$ & $60000 \pm 3000^{c}$ \\
\hline$M_{\mathrm{r}}$ (native) & 240000 & $240000 \pm 5000^{\circ}$ & $230000^{c}$ \\
\hline $\begin{array}{l}\text { Specific activity } \\
\text { [units (mg } \\
\text { protein })^{-1} \text { ] }\end{array}$ & 103 & $120^{b}$ and $134 \cdot 2^{a}$ & $51.9^{d}$ \\
\hline$K_{\text {cat }}\left(\min ^{-1}\right)$ & 24720 & 32208 & 12456 \\
\hline $\begin{array}{l}S_{0 \cdot 5} \text { or } K_{\mathrm{m}} \text { for } \\
\text { pyruvate }(\mathrm{mM})\end{array}$ & 13 & $0 \cdot 3^{b}$ and $4 \cdot 4^{a}$ & $3^{e}$ \\
\hline pH optimum & $6 \cdot 3-6 \cdot 7$ & $6.0^{b}$ & $5 \cdot 4-5 \cdot 8^{f}$ \\
\hline
\end{tabular}

References: $a$, Hoppner \& Doelle (1983); $b$, Neale et al. (1987a); $c$, Gounaris et al. (1975); $d$, Ullrich et al. (1966); e, Ullrich \& Donner (1970); $f$, Jordan et al. (1978).

The very low affinity for pyruvate of pyruvate decarboxylase from $S$. ventriculi could possibly have been due to the absence of a positive effector, for example a metal ion. The enzyme was incubated in 25 mM-EGTA at $37^{\circ} \mathrm{C}$ for $20 \mathrm{~h}$ without loss of activity, suggesting that either metal ions were not required for activity or, if present, the association between the enzyme and the metal was so strong that EGTA could not remove the metal.

A number of inhibitors of $S$. ventriculi pyruvate decarboxylase were identified, including glyoxylate ( $2 \mathrm{mM}$ caused $82 \%$ reduction in activity), which is an inhibitor of TPP-containing enzymes, forming a noncleavable bond with the catalytic centre of TPP (Flatau et al., 1988). Glyoxylate inhibits pyruvate synthase from Clostridium kluyveri and Clostridium pasteurianum (Thauer et al., 1970), and pyruvate decarboxylase from Sacch. cerevisiae (Uhlemann \& Schellenberger, 1976). Ethanol is the end product of the pathway for pyruvate metabolism and concentrations of $150 \mathrm{mM}$ are formed

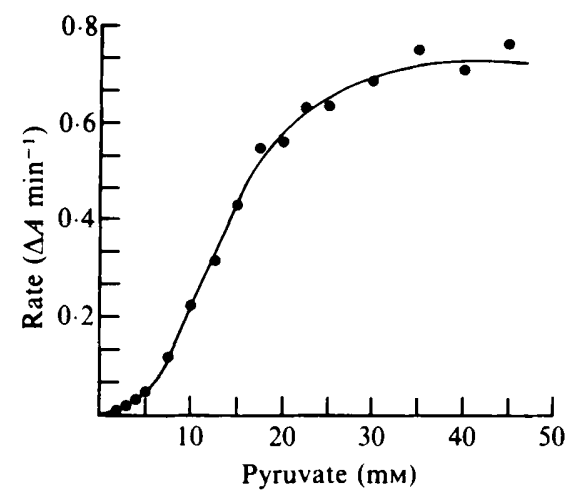

Fig. 2. Kinetics of purified pyruvate decarboxylase for pyruvate. The data represent mean results from duplicate determinations, and are representative of data obtained from pyruvate decarboxylase purified on three separate occasions.

during the fermentation of glucose, but 100 mM-ethanol caused only a slight reduction $(22 \%)$ in pyruvate decarboxylase activity. Phosphate increased the cooperativity and decreased the apparent affinity for pyruvate of pyruvate decarboxylase from Sacch. cerevisiae (Boiteux \& Hess, 1970), but $100 \mathrm{~mm}$-phosphate had no effect on pyruvate decarboxylase from $S$. ventriculi.

Pyruvate decarboxylase activity was inhibited by the presence of $\mathrm{ZnCl}_{2}$, with $0.5 \mathrm{mM}$ causing $82 \%$ reduction in activity; this inhibition was reversed by the addition of $5 \mathrm{~mm}$-cysteine, which restored $65 \%$ of the total activity. Inhibition of pyruvate decarboxylase by $p$ chloromercuribenzoate $(40 \mu \mathrm{M}$ resulted in $45 \%$ reduction in activity) occurred in the absence of pyruvate, whereas in the presence of pyruvate $p$-chloromercuribenzoate had no effect, indicating the importance of cysteine in the active site of this enzyme. The action of $p$-chloromercuribenzoate could be reversed by the addition of $5 \mathrm{~mm}$ dithiothreitol. The metal ions $\mathrm{Mg}^{2+}, \mathrm{Mn}^{2+}, \mathrm{Co}^{2+}$ and $\mathrm{Ca}^{2+}$ (each $\left.2 \mathrm{mM}\right)$ did not increase enzyme activity or alter the kinetic properties of pyruvate decarboxylase at pyruvate concentrations from $3 \mathrm{mM}$ to $20 \mathrm{mM}$.

As none of the metal ions tested were positive effectors, a number of metabolic intermediates were examined to determine their effect on pyruvate decarboxylase activity. These included acetyl-CoA, CoA, acetyl phosphate, ATP, fructose 1,6-diphosphate and phosphoenol pyruvate, at varying concentrations up to $2 \mathrm{mM}$, and cAMP $(14-100 \mu \mathrm{M})$, with $9 \mathrm{mM}$-pyruvate. All the concentrations of acetyl-CoA $(0.1 \mathrm{mM}$ to $2 \mathrm{mM})$ caused approximately $27 \%$ loss in activity. Higher levels of acetyl phosphate ( $2 \mathrm{~mm})$ and ATP $(0.5 \mathrm{~mm})$ decreased enzyme activity by $43 \%$ and $29 \%$, respectively. The other metabolites did not alter pyruvate decarboxylase activity. It was not possible to ascertain the effect of 


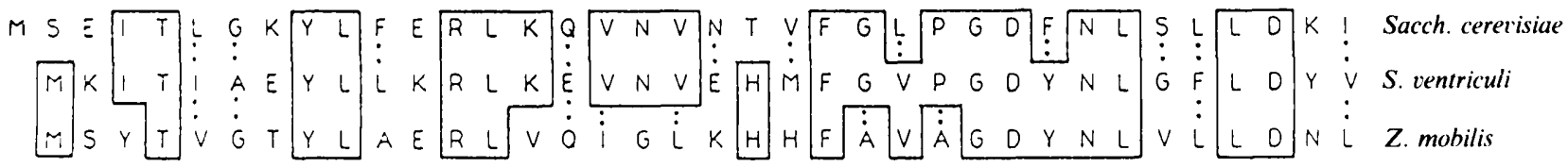

Fig. 3. The N-terminal amino acid sequence of purified pyruvate decarboxylase from $S$. ventriculi compared with the sequences of pyruvate decarboxylase from $Z$. mobilis and Sacch. cerevisiae using the Bestfit program of the Genetics Computer Group Sequence Analysis Software Package (Devereux et al., 1984). The boxed areas contain amino acids which directly match, : represents a conservative amino acid change.

Table 3. Relative amino acid composition of pyruvate decarboxylase from $S$. ventriculi, $Z$. mobilis and Sacch. cerevisiae

\begin{tabular}{|c|c|c|c|}
\hline \multirow[b]{2}{*}{$\begin{array}{l}\text { Amino } \\
\text { acid }\end{array}$} & \multicolumn{3}{|c|}{ Composition $(\mathrm{mol} \%)^{*}$} \\
\hline & $\begin{array}{l}\text { S. ventriculia } \\
\text { (this study) }\end{array}$ & Z. mobilis $^{b}$ & $\begin{array}{c}\text { Sacch. } \\
\text { cerevisiae }\end{array}$ \\
\hline Asx & $8 \cdot 7$ & $10 \cdot 2$ & $10 \cdot 2$ \\
\hline Glx & $10 \cdot 7$ & $8 \cdot 6$ & 8.9 \\
\hline Ser & 5.5 & $4 \cdot 2$ & $6 \cdot 0$ \\
\hline Gly & $7 \cdot 3$ & $8 \cdot 1$ & 7.8 \\
\hline His & $1 \cdot 1$ & $2 \cdot 1$ & $2 \cdot 0$ \\
\hline Arg & $4 \cdot 1$ & $3 \cdot 0$ & 2.7 \\
\hline Thr & $6 \cdot 1$ & $4 \cdot 6$ & $7 \cdot 7$ \\
\hline Ala & $7 \cdot 2$ & 15.0 & $8 \cdot 2$ \\
\hline Pro & $2 \cdot 7$ & $4 \cdot 8$ & 4.6 \\
\hline Tyr & $3 \cdot 2$ & 3.9 & $3 \cdot 1$ \\
\hline Val & 6.8 & 7.8 & 7.5 \\
\hline Met & $2 \cdot 1$ & 1.9 & $2 \cdot 4$ \\
\hline Ile & $6 \cdot 1$ & 4.9 & 6.6 \\
\hline Leu & 7.8 & 8.8 & 9.7 \\
\hline Phe & $16 \cdot 2$ & $3 \cdot 2$ & $4 \cdot 2$ \\
\hline Lys & 4.4 & $6 \cdot 3$ & $6 \cdot 2$ \\
\hline Cys & ND & $1 \cdot 2$ & $1 \cdot 1$ \\
\hline Trp & ND & $1 \cdot 2$ & $1 \cdot 3$ \\
\hline Total & 100 & 99.8 & $100 \cdot 2$ \\
\hline Hydrophobic & 48.9 & $45 \cdot 3$ & $49 \cdot 2$ \\
\hline Hydrophilic & 43.8 & $46 \cdot 4$ & $43 \cdot 2$ \\
\hline
\end{tabular}

ND, Not determined.

* References: $a$, this study; $b$, Neale et al. $(1987 b) ; c$, Kellerman et al. (1986).

acetaldehyde on pyruvate decarboxylase activity as this compound is the substrate for the coupling assay with alcohol dehydrogenase.

The N-terminal amino acid sequence of pyruvate decarboxylase from $S$. ventriculi was compared to the sequences of $Z$. mobilis and Sacch. cerevisiae pyruvate decarboxylase (Fig. 3). There was $86 \%$ similarity and $54 \%$ identity in the $\mathrm{N}$-terminal region of pyruvate decarboxylase from $S$. ventriculi compared with the enzyme from Sacch. cerevisiae, and $69 \%$ similarity and $44 \%$ identity between the $S$. ventriculi enzyme and the $Z$. mobilis enzyme. Comparison of the total amino acid composition of pyruvate decarboxylase from the three organisms (Table 3 ) did not reveal any great similarities. $Z$. mobilis pyruvate decarboxylase had a very high content of alanine (Neale et al., 1987b), and the enzyme from $S$. ventriculi was high in phenylalanine.

The amount of pyruvate decarboxylase protein increases when $S$. ventriculi is grown at low $\mathrm{pH}$, corresponding to the increase in carbon and electron flow through the non-oxidative branch of the pathway for pyruvate metabolism (Lowe \& Zeikus, 1991), suggesting that in vivo enzyme activity is not increased by altering the kinetics of the enzyme due to the presence of positive effectors, but rather by increasing the amount of protein synthesized. From a previous study using crude extract from cells of $S$. ventriculi, the $K_{\mathrm{m}}$ for pyruvate of pyruvate dehydrogenase was $2.5 \mathrm{~mm}$ (Lowe \& Zeikus, 1991). As this enzyme has a much higher affinity for pyruvate than does pyruvate decarboxylase, increased flux through the non-oxidative branch of the pathway could be achieved by the presence of activators or increased synthesis of pyruvate decarboxylase. Our studies failed to identify any positive effectors, and increased levels of a protein with an $M_{\mathrm{r}}$ corresponding to pyruvate decarboxylase occur in cells grown at low $\mathrm{pH}$ compared to neutral $\mathrm{pH}$ (Lowe \& Zeikus, 1991), suggesting that pyruvate decarboxylase synthesis rather than activity is increased when $S$. ventriculi is grown at acid $\mathrm{pH}$.

This research was supported by funds from the Center for Microbial Ecology, a National Science Foundation and Technology Center at Michigan State University, to S.E.L. and by DOE grant DE-FG0287ER-13719 for J.G.Z. We would like to thank Saroj Mathupala for very helpful advice and useful discussions.

\section{References}

BorteuX, A. \& Hess, B. (1970). Allosteric properties of yeast pyruvate decarboxylase. FEBS Letters 9, 293-296.

BradFoRd, M. M. (1976). A rapid and sensitive method for the quantitation of microgram quantities of protein utilizing the principle of protein-dye binding. Analytical Biochemistry 72, 248-254.

DE LEY, J. \& SCHELl, J. (1959). Studies on the metabolism of Acetobacter peroxydans. II. The enzymic mechanism of lactate metabolism. Biochimica et Biophysica Acta 35, 154-165.

DeVereuX, J., Haeberli, P. \& Smithies, O. (1984). A comprehensive set of sequence analysis programs for the VAX. Nucleic Acids Research 12, 387-395.

Flatau, S., Fischer, G., Kleinpeter, E. \& Schellenberger, A. (1988). ${ }^{31} \mathrm{P}$ NMR investigations on free and enzyme bound thiamine pyrophosphate. FEBS Letters 233, 379-382. 
Goodwin, S. \& Zeikus, J. G. (1987). Physiological adaptations of anaerobic bacteria to low $\mathrm{pH}$ : metabolic control of proton motive force in Sarcina ventriculi. Journal of Bacteriology 169, 2150-2157.

Gounaris, A. D., Turkenkopf, I., Buckwald, S. \& Young, A. (1971). Pyruvate decarboxylase. I. Protein dissociation into subunits under conditions in which thiamine pyrophosphate is released. Journal of Biological Chemistry 246, 1302-1309.

Gounaris, A. D., Turkenkopf, I., Civerchia, L. L. \& Greenlie, J. (1975). Pyruvate decarboxylase. III. Specificity restrictions for thiamine pyrophosphate in the protein association step, sub-unit structure. Biochimica et Biophysica Acta 405, 492-499.

HAQ, A. \& DAwES, E. A. (1971). Pyruvic acid metabolism and ethanol formation in Erwinia amylovora. Journal of General Microbiology 68, 295-306.

Hoppner, T. C. \& Doelle, H. W. (1983). Purification and kinetic characteristics of pyruvate decarboxylase and ethanol dehydrogenase from Zymomonas mobilis in relation to ethanol production. European Journal of Applied Microbiology and Biotechnology 17, 152-157.

JoRdan, F., KUo, D. J. \& MONSE, E. U. (1978). A pH-rate determination of the activity-pH profile of enzymes. Application to yeast pyruvate decarboxylase demonstrating the existence of multiple ionizable groups. Analytical Biochemistry 86, 298-302.

Kellerman, E., Seeboth, P. G. \& Hollenberg, C. P. (1986). Analysis of the primary structure and promoter function of a pyruvate decarboxylase gene (PDC1) from Saccharomyces cerevisiae. Nucleic Acids Research 14, 8963-8977.

King, T. \& Cheldelin, V. H. (1954). Pyruvic carboxylase of Acetobacter suboxydans. Journal of Biological Chemistry 208, 821-831.
LaEmmLI, U. K. (1970). Cleavage of structural proteins during the assembly of the head of bacteriophage T4. Nature, London 227, 680-685.

LOWE, S. E. \& ZeIKus, J. G. (1991). Metabolic regulation of carbon and electron flow as a function of $\mathrm{pH}$ during growth of Sarcina ventriculi. Archives of Microbiology 155, 325-329.

MOENCH, T. T. \& ZeIKUS, J. G. (1983). An improved preparation method for a titanium(III) media reductant. Journal of Microbiological Methods 1, 199-202.

Neale, A. D., Scopes, R. K., Wettenhall, R. E. H. \& Hoogenraad, N. J. (1987a). Pyruvate decarboxylase of Zymomonas mobilis: isolation, properties, and genetic expression in Escherichia coli. Journal of Bacteriology 169, 1024-1028.

Neale, A. D., Scopes, R. K., Wettenhall, R. E. H. \& Hoogenraad, N. J. (1987b). Nucleotide sequence of the pyruvate decarboxylase gene from Zymomonas mobilis. Nucleic Acids Research 15, 1753-1761.

Stephenson, M. P. \& Dawes, E. A. (1971). Pyruvic acid and formic acid metabolism in Sarcina ventriculi and the role of ferredoxin. Journal of General Microbiology 69, 331-343.

Thauer, R. K., Rupprecht, E. \& JungermanN, K. (1970). Glyoxylate inhibition of clostridial pyruvate synthase. FEBS Letters 9, 271-273.

UhlemanN, H. \& SChellenberger, A. (1976). Glyoxylic acid as an active site marker of yeast pyruvate decarboxylase. FEBS Letters 63 , 37-39.

UlLRICH, J. \& DONNER, I. (1970). Kinetic evidence for two active sites in cytoplasmic yeast pyruvate decarboxylase. Hoppe-Seyler's Zeitschrift für Physiologische Chemie 350, 1026-1029.

UllRiCh, J., WitToRF, J. H. \& GUBler, C. J. (1966). Molecular weight and coenzyme content of pyruvate decarboxylase from brewer's yeast. Biochimica et Biophysica Acta 113, 595-604. 